\title{
Manajemen Konflik Sebuah Solusi (Pandangan Islam)
}

\author{
H. Al Asy'ari \\ Dosen Fakultas Dakwah dan Komunikasi UIN Sumatera Utara \\ Email: Asari uinsu@yahoo.co.id
}

\begin{abstract}
ABSTRAK: Konflik bagian yang tidak terpisahkan dari kehidupan umat manusia, Konflik muncul bukan dengan tiba-tiba, tetapi konflik sudah terpuruk sejak awal manusia memulai aktifitasnya tempat dia bekerja. Konflik dengan diri sendiri dapat terjadi pada individu apabila antara hati nurani dengan akalnya tidak sejalan atau bertentangan. perselisihan atau pertentangan dua orang atau dua kelompok terhadap suatu gagasan yang mereka tidak dapat mencapai kata sepakat atau kata setuju. Sepakat atau ketidaksepakatan dapat saja dilatar belakangi oleh perbedaan pengalaman pengetahuan tentang gagasan, sehingga menimbulkan gangguan kepada salah satu atau kedua belah pihak. Kondisi ini tentu membuat masing-masing pihak tidak merasa nyaman untuk melakukan interaksi. Interaksi yang tidak didasarkan pada kelapangan dada atau ketulusan dapat menyebabkan masingmasing individu atau kelompok menjadi tertutup akibat komunikasi tersumbat. Ada dua dasar yang menyebabkan pentingnya manajemen konflik: pertama Dari sisi Kedudukan Manusia.

Kedua Dari sisi Organisasi. Manajemen adalah aktivitas mengatur dalam upaya mencapai tujuan yang diinginkan secara efektif dan efesien. Pencapaian tujuan dilakukan melalui pemanfaatan sumber daya, sarana dan kerjasama terhadap sejumlah orang. Jadi tidaklah salah bila dikatakan manajemen merupakan proses sosial yang mengatasi segalanya. Maka dari itu manajemen sangat penting untuk mengelola konflik sehingga tujuan untuk memakmurkan bumi dapat tercapai. Sedangkan dalam organisasi mengelola konflik sangat penting artinya agar tujuan organisasi dapat tercapai karena semua sumber daya yang ada diarahkan pada pencapaian tujuan.
\end{abstract}

\section{Kata Kunci: Konflik, Manajemen,dan Solusi}

\section{Pendahuluan}

Konplik merupakan bagian yang tidak terpisahkan dari kehidupan umat manusia, baik sebagai individu, anggota masyarakat maupun sebagai anggota organisasi. Potensi terciptanya konflik sama tuanya dengan keberadaan umat manusia karena sejak Allah menciptakan Adam, Iblis telah memulai konflik ketika ia menolak untuk sujud kepada Adam sebagaimana yang diperintahkan Rabnya. Konflik terlihat ketika Iblis meminta kepada Rab agar diberi tangguh sampai hari berbangkit dengan tujuan untuk menciptakan berbagai konflik terhadap keturunan Adam sehingga neraka dipenuhi dengan para pengikutnya.

Konflik berikutnya terjadi pada dua anak Nabi Adam, Habil dan Qobil yang berujung terbunuhnya salah satu anak Adam yaitu Habil. Konflik ini dimulai adanya rasa dengki dan iri hati, sebab korban Habil diterima oleh Allah sedangkan korban Qobil tidak. Allah menceritakan kisah ini (Q.S.5:27): “Ceritakanlah kepada mereka kisah kedua putra Adam (Habil dan Qobil) menurut yang sebenarnya, ketika keduanya mempersembahkan korban, maka diterima dari salah seorang dari mereka berdua (Habil) dan tidak diterima dari yang 
lain (Qobil). Ia berkata (Qobil); “Aku pasti membunuhmu”. Berkata Habil; "Sesungguhnya Allah hanya menerima (Korban) dari orang-orang yang bertakwa”. Inilah awal pertumpahan darah anak manusia sebagai wujud janji Iblis kepada Allah untuk menggoda anak cucu Adam. Demikianlah seterusnya konflik menyertai hidup dan kehidupan manusia tiada henti sampai sekarang bahkan sampai kiamat datang.

Hukum kekekalan energi ada menyebutkan bahwa energi tidak dapat dimusnahkan tetapi energi dapat diubah menjadi bentuk energi lain. Demikian juga konflik tidak dapat dihilangkan dari kehidupan manusia, namun konflik dapat dicarikan solusi atau pemecahannya sehingga terwujud ketenangan dan perdamaian. Jika saja konflik dihilangkan dari kehidupan manusia, maka manusia yang hidup diakhir zaman akan menikmati hidup dalam kedamaian. Namun nyatanya konflik ada dimana-mana, hidup menjadi merana dan harta benda serta jiwa hilang adanya. Konflik terjadi karena adanya perbedaan pandangan, persepsi dan tujuan antara satu individu atau kelompok dengan individu atau kelompok lain. Perbedaan tersebut dapat diakibatkan oleh latar belakang pendidikan, budaya, keyakinan, ekonomi maupun politik. Jika demikian, maka potensi konflik selalu mengikuti setiap langkah kehidupan manusia sebagaimana disebutkan Allah dalam Alquran (Q.S.10:19); "Manusia dahulunya hanyalah satu umat, kemudian mereka berselisih". ${ }^{2}$ Jadi konflik sudah merupakan sunnatullah/ketetapan Allah bagi manusia, karenanya sangat relevan sekali dakwah menjadi sarana untuk menyampaikan pesan Ilahiyah kepada segenap manusia agar mengikuti jalannya. Oleh sebab itulah Allah menurunkan Nabi dan Rasulnya.

\section{Definisi Manajemen dan Konflik}

Manajemen berasal dari bahasa Inggris asal katanya to manage yang artinya mengatur. Sementara dalam bahasa Arab, manajemen diartikan an-nizam atau at-tanzhim artinya tempat untuk menyimpan sesuatu, penempatan sesuatu pada tempatnya. Jadi secara bahasa manajemen dapat diartikan aktivitas menertibkan, mengatur dan berpikir seseorang, sehingga ia mampu mengemukakan, menata dan merapikan sesuatu yang ada di sekitarnya, menjadikan selaras dan serasi satu dengan lainnya. ${ }^{3}$

Menurut istilah, manajemen adalah ilmu dan seni mengatur proses pemanfaatan sumber daya manusia dan sumber-sumber lainnya secara efektif dan efesien untuk mencapai

\footnotetext{
${ }^{1}$ Depag RI. al-Qur'an dan Terjemahnya. (Bandung: CV. Gema Risalah Press: 1993),h.163.

${ }^{2}$ Ibid. h.308.

${ }^{3}$ M. Munir dan Wahyu Ilahi, Manajemen Dakwah (Jakarta: Kencana, 2006), h.9.
} 
suatu tujuan tertentu. ${ }^{4}$ Dapat dipahami bahwa manajemen adalah aktivitas mengatur dalam upaya mencapai tujuan yang diinginkan secara efektif dan efesien. Pencapaian tujuan dilakukan melalui pemanfaatan sumber daya, sarana dan kerjasama terhadap sejumlah orang. Jadi tidaklah salah bila dikatakan manajemen merupakan proses sosial yang mengatasi segalanya.

Sementara konflik menurut Kamus Besar Bahasa Indonesia adalah percekcokan, perselisihan dan pertentangan. ${ }^{5}$ Sedangkan dari sisi istilah konflik menurut Hardjana yang dikutip oleh Wahyudi, didefinisikan sebagai "perselisihan, pertentangan atara dua orang/dua kelompok dimana perbuatan yang satu berlawanan dengan yang lainnya sehingga salah satu atau kedunya saling terganggu. ${ }^{6}$

Definisi di atas memberi gambaran bahwa konflik merupakan perselisihan atau pertentangan dua orang atau dua kelompok terhadap suatu gagasan yang mereka tidak dapat mencapai kata sepakat atau kata setuju. Ketidaksepakatan dapat saja dilatar belakangi oleh perbedaan pengalaman atau pengetahuan tentang gagasan, sehingga menimbulkan gangguan kepada salah satu atau kedua belah pihak. Kondisi ini tentu membuat masing-masing pihak tidak merasa nyaman untuk melakukan interaksi. Interaksi yang tidak didasarkan pada kelapangan dada atau ketulusan dapat menyebabkan masing-masing individu atau kelompok menjadi tertutup akibat komunikasi tersumbat. Komunikasi sangat penting artinya dalam melakukan interaksi karena dengan komunikasi "memungkinkan individ-individu membangun suatu kerangka rujukan dan menggunakannya sebagai panduan untuk menafsirkan situasi apapun yang ia hadapi". ${ }^{7}$ Komunikasi yang tersumbat mempercepat konflik menjadi besar dan melebar karena sudah tidak ada hubungan yang harmonis lagi. Hal tersebut dapat dilihat akibatnya yaitu terjadi peperangan dimana-mana merupakan contoh nyata konflik terbuka yang berakibat fatal yaitu timbulnya korban harta dan jiwa.

\section{Arti Penting Manajemen Konflik}

Ada dua dasar yang menyebabkan pentingnya manajemen konflik.

1. Dari sisi Kedudukan Manusia

\footnotetext{
${ }^{4}$ Malayu SP Hasibuan, Manajemen Sumber Daya Manusia (Jakarta:Bumi Aksara,2000), h.1.

${ }^{5}$ Departemen Pendidikan dan Kebudayaan. Kamus Besar Bahasa Indonesia ( Jakarta: Balai Pustaka, 1995), h. 518.

${ }^{6}$ Wahyudi, Manajemen Konflik dalam Organisasi (Bandung: Alfabeta,2011), h.9

${ }^{7}$ Deddy Mulyana. Ilmu Komunikasi Suatu Pengantar (bandung: Remaja Rosdakrya,2000), h.5.
} 
Manusia berkedudukan sebagai khalifah di permukaan bumi, sementara konflik sudah menjadi ketetapan Allah yang tidak dapat diubah. Artinya manusia sebagai khalifah akan senantiasa menghadapi konflik secara terus menerus karena Allah telah menetapkan bahwa sebagian manusia menjadi musuh bagi sebagian manusia yang lain. Kejadian ini akan terjadi terus menerus sampai hari kiamat. Allah berfirman (Q.S.2:36); "Turunlah kamu! Sebahagian kamu menjadi musuh bagi yang lain". ${ }^{8}$

Sangat jelas bahwa permusuhan merupakan puncak konflik. Jika manusia yang berkedudukan sebagai khalifah tidak dapat mengola konflik, maka sudah dapat dipastikan kedamaian tidak akan terwujud dan kemakmuranpun akan terabaikan. Inilah tugas para Nabi dan Rasul serta orang-orang yang mengikuti jalannya. Oleh karena itu orang mukmin sangat berbeda sekali dengan orang kafir dalam segala aspeknya. Orang kafir selalu berusaha untuk menciptakan konflik/permusuhan sementara orang mukmin selalu berusaha menciptakan perdamaian. "Sebenarnya orang-orang kafir itu (berada) dalam kesombongan dan permusuhan yang sengit"'(Q.S.38:2). ${ }^{9}$

Dari uraian di atas, makna pentingnya manajemen konflik berarti; Pertama, tugas pokok sebagai khalifah di permukaan bumi untuk menciptakan perdamaian sehingga tercapai tujuan memakmurkan bumi. Kedua, merupakan ciri khusus orang-orang mukmin dalam rangka amar makruf nahi munkar yang menjadi tanggung jawabnya.

2. Dari sisi Organisasi

Organisasi dibentuk karena memiliki tujuan yang ingin dicapai oleh organisasi. Dalam organisasi terdapat kumpulan orang-orang yang memiliki tujuan bersama. Tujuan bersama dapat dicapai manakala semua kelompok dalam organisasi terlibat secara aktif. Maju tidaknya sebuah organisasi dipengaruhi oleh faktor lingkungan, baik lingkungan internal maupun lingkungan eksternal. Lingkungan internal berasal dari dalam organisasi sedangkan lingkungan eksternal berasal dari luar organisasi yang tidak dapat dikuasai seperti lingkungan politik, lingkungan budaya dan lain sebagainya. ${ }^{10}$

Organisasi yang ingin maju tentu harus senantiasa dapat menyusun strategi yang baik sebagai respon terhadap perubahan lingkungan yang selalu berubah dan terus mengembangkan potensi sumber daya yang berkesinambungan. Interaksi antar individu dalam organisasi sebagai wujud dari kerjasama untuk mencapai tujuan tentunya tidak selalu paralel dengan aturan organisasi yang ditetapkan, karena setiap individu dalam prilaku selalu

\footnotetext{
${ }^{8}$ Depag RI.al-Qur'an, h.15.

${ }^{9}$ Ibid, h.733.

${ }^{10}$ Sondang P. Siagian, Manajemen Stratejik (Jakarta: PT.Bumi Aksara,2001), h. 33-34
} 
dipengaruhi oleh pengalaman, pengetahuan, watak dan tempramen. Dalam kondisi ini benturan-benturan dalam menterjemahkan aturan selalu terjadi karena masing-masing individu sebagai anggota organisasi melakukan kompetisi atau persaingan yang tidak jarang menimbulkan konflik. Sebagaimana diketahui bahwa konflik yang ditimbulkan oleh individu atau kelompok dalam organisasi dapat mempengaruhi jalannya roda organisasi dalam mencapai tujuan, karnanya manajemen konflik menjadi penting artinya untuk mengendalikan konflik yang mungkin terjadi dalam organisasi. ${ }^{11}$

\section{Pandangan Tentang Konflik}

Ada dua pandangan tentang konplik, yaitu;

1. Pandangan Tradisional

Dalam pandangan ini konflik adalah suatu yang negatif dan sebab itu harus dihilangkan atau dimusnahkan karena menjadi sumber terhambatnya kemajuan baik dalam masyarakat maupun dalam organisasi. Konsekuensi pandangan ini adalah dilakukan tindakantindakan yang ditujukan untuk menghilangkan sumber konflik. Kenyataan ini dapat dilihat dengan nyata ketika Pemerintah Orde Baru menerapkan kebijakan Daerah Operasi Militer (DOM) di Aceh, sebagai langkah ofensif untuk menghilangkan konflik yang berkepanjangan. Namun apa yang terjadi konflik tidak pernah hilang dan penderitaan masyarakat semakin hari semakin parah.

Mitos yang berkembang tentang konflik menurut pandangan tradisional dalam organisasi antara lain; ${ }^{12}$

a. Adanya konflik sebagai pertanda lemahnya manajer

Manajer dinilai ada tidaknya konflik yang berkembang dalam unitnya. Jika konflik ada dan berkembang berarti manajer dinilai lemah dan dianggap tidak mampu. Manajer tidak cakap dalam mengelola sumber daya yang dimilikinya. Hal ini bisa disebabkan karena pengalaman dan pengetahuan manajer yang masih kurang mumpuni atau dapat juga manajer tidak dapat menangkap maksud dari tujuan organisasi sehingga salah dalam menafsirkannya.

b. Konflik pertanda rendahnya perhatian terhadap organisasi

Perhatian penuh memang harus dicurahkan untuk organisasi agar dapat mencapai prestasi. Jika konflik berkembang dalam organisasi menurut anggapan tradisional ini

\footnotetext{
${ }^{11}$ Wahyudi. Manajemen Konflik, h.14.

${ }^{12}$ William Hendricks, How to Manage Conflict, Terjemahan: Arif Santoso, Bagaimana Mengelola Konflik, (Jakarta: PT.Bumi Aksara:2012), h. 2-4.
} 
pertanda perhatian para Man (manusia) yang ada dalam organisasi lemah terhadap organisasi.

c. Konflik negatif dan merusak

Semua orang jika ditanya apakah konflik atau pertentangan itu buruk? Sudah dapat dipastikan sebagian besar akan menjawab "ya". Jawaban ini menandakan bahwa konflik sebagai hal yang buruk dan negatif masuk dalam pandangan tradisional yang sudah berkembang sejak masa manajemen klasik 1900-1940. Pada masa ini memang konflik dianggap sesuatu yang merusak dan menghambat kemajuan organisasi sehingga konflik harus dihilangkan. Namun kenyataannya pandangan ini masih ada pada Top Manajemen yang masih menganutnya.

d. Konflik bila dibiarkan akan reda dengan sendirinya.

Sungguh sangat keliru pandangan semacam ini bahwa konflik bila dibiarkan akan mereda dengan sendirinya. Sebaiknya konflik yang dibiarkan berkembang akan menjadi bom waktu yang sewaktu-waktu akan meledak. Pandangan ini mengakibatkan tidak adanya langkah-langkah konkrit yang dilakukan untuk handling konflik yang berkembang tersebut.

e. Konflik harus dipecahkan

Konflik harus dipecahkan, jika tidak dapat menyebabkan tujuan organisasi tidak akan tercapai. Dengan asumsi ini berarti semua sumber daya yang ada selalu diarahkan untuk memecahkan konflik yang terjadi. Dapat dibayangkan bila semua potensi organisasi mengarah pada pemecahan konflik pasti pencapaian tujuan organisasi akan terabaikan. Organisasi akan mengalami kerugiaan baik waktu, dana maupun tenaga. Rencana yang sudah disusun serta strategi untuk mencapainya menjadi sia-sia karena tidak ada sumber daya yang secara penuh diarahkan untuk melaksanakan strategi dan mencapai tujuan.

Dari pembahasan di atas, dapat ditarik suatu pemahaman bahwa konflik yang terjadi dalam organisasi menurut pandangan tradisional karena adanya kesalahan manajemen dalam membuat perencanaan organisasi, sehingga terhalangnya pencapaian tujuan organisasi. Oleh sebab itu konflik harus dihindari bila perlu dihilangkan. ${ }^{13}$

1. Pandangan Modern

Menurut pandangan modern, konflik bukan merupakan suatu hal yang buruk ataupun negatif, tetapi dapat dipandang sebagai kompetisi antar individu ataupun antar kelompok.

\footnotetext{
${ }^{13}$ Ibid, h. 25-26
} 
Pandangan ini membagi konflik menjadi dua yaitu konflik fungsional dan konflik disfungsional. Konflik fungsional berarti terjadi persaingan individu-individu atau kelompok sehingga memicu kinerja organisasi yang semakin meningkat. Sedangkan konflik yang bersifat disfungsional berarti terganggunya interaksi antar individu atau kelompok yang menghambat atau menghalangi tercapainya tujuan organisasi secara maksimal.

Melihat kenyataan tersebut, maka konflik yang dimaknai secara positif dapat menimbulkan :

a. Bersifat konstruktif

Persaingan yang bersifat konstruktif berarti akan menambah gairah kerjasama anggota kelompok organisasi dalam rangka untuk meningkatkan prestasi masing-masing individu. Persaingan ini akan mengubah karakter dan cara pandang setiap anggota kelompok terhadap diri kelompoknya. Pada moment ini manajer lebih banyak terlibat untuk tetap melakukan kontrol agar persaingan sesuai koridor organisasi.

b. Perhatian penuh pada pencapaian tujuan organisasi

Jika konflik dimaknai sebagai hal positif, maka anggota organisasi akan mencurahkan tenaga dan pikiran untuk mencapai tujuan organisasi. Setiap anggota organisasi boleh berkompetisi dan organisasi memberikan ruang yang cukup untuk hal tersebut. Konflik yang muncul bukan sebagai hambatan tetapi sebagai alat untuk mempercepat pencapaian tujuan bahkan organisasi dapat menciptakan konflik yang positif.

c. Menciptakan kreatifitas dan harmonisasi hubungan anggota organisasi

Tidak dapat diingkari konflik fungsional (positif) menjadi pemicu untuk melakukan kreatifitas dan mempererat hubungan kelompok. Hal ini akan meningkatkan kerja dan tanggung jawab.

d. Mengurangi gangguan psikologis

Hal positif lainnya dari konflik yang positif adalah dapat mengurangi ketegangan anggota organisasi dalam bekerja. Mereka melakukan pekerjaan dalam suasana kompetisi yang sehat dan terbebas dari tekanan-tekanan psikologis baik yang datang dari internal diri sendiri maupun dari eksternal. Memang tidak dapat dipungkiri bahwa konflik terkadang membawa suasana gaduh dan ketegangan baik bagi individu, masyarakat maupun organisasi, sehingga dapat mengganggu kenyamanan dan ketenangan semua pihak.

Dari uraian di atas, konflik bila tidak dikelola secara profesional maka akan besar sekali dampaknya bagi perjalanan hidup umat manusia. Sekali lagi konflik tidak dapat 
dihilangkan, tetapi dapat dikelola atau dimanfaatkan untuk kepentingan individu, kelompok dan organisasi. Apabila konflik dihilangkan sama artinya menghilangkan kehidupan manusia itu sendiri.

Sejalan dengan makna konflik secara positif, Islam dengan segala aspek ajaran moralnya sejak 1400 tahun yang lalu sudah memandang konflik bukan dari segi negatif. Konflik tercipta sejak diciptakannya Adam. Iblis yang tidak mau sujud kepada Adam sebagaimana yang diperintahkan Allah sudah memulai konflik. Iblis disatu sisi sedangkan Adam dan anak keturunannya di sisi yang lain terus berkompetisi untuk membawa umat manusia kejalan mereka masing-masing.

Alquran memberikan motivasi, dalam surah Al Maidah (Q.S.5:48) yang artinya; "Kami berikan aturan dan jalan yang terang. Sekiranya Allah menghendaki, niscaya kamu dijadikan-Nya satu umat (saja), tetapi Allah hendak menguji kamu terhadap pemberian-Nya kepadamu, maka berlomba-lombalah berbuat kebajikan. Hanya kepada Allah-lah kembali kamu semuanya, lalu diberitahukan-Nya kepadamu apa yang telah kamu perselisihkan itu". ${ }^{4}$

Ada hikmah dibalik pembangkangan Iblis, sehingga manusia saling berlomba untuk berbuat kebaikan mencari ridha Ilahi. Sisi inilah kompetisi amaliyah dinilai olehnya. Pada sisi lain, anjuran Allah untuk saling tolong menolong dalam kebaikan dan ketakwaan menjadi dorongan yang kuat bahwa dengan segala dimensinya kerjasama dalam kebaikan merupakan syarat mutlak bagi organisasai untuk mencapai tujuannya. Dimensi ini akan menghilangkan semua sekat penghambat antar individu dan kelompok. Seruan untuk bekerjasama dalam kebaikan dan ketakwaan memandang bahwa manusia saling membutuhkan satu sama lain untuk memenuhi kebutuhan. Manusia sebagai makhluk sosial tidak bisa hidup sendiri. Pemenuhan kebutuhan membawa manusia pada satu titik persaingan yang terkadang persaingan itu membawa perpecahan dan permusuhan (konflik). Teori evolusi Darwin, sekalipun tidak sesuai dengan Islam, masih dipegang oleh ilmuan Barat yang menyatakan bahwa yang kuat saja dapat survive sementara yang lemah akan lenyap/kalah. Teori ini setidaknya menyingkirkan peran Allah dalam proses kelangsungan hidup manusia dipermukaan bumi sebagaimana yang diajarkan Islam.

Konsep tolong menolong dalam kebaikan dan ketakwaan mengantarkan manusia sebagai anggota masyarakat untuk tetap memandang positif pihak atau kelompok lain sekalipun berlainan latar belakang keyakinan, budaya, ekonomi dan politik. Anggota

\footnotetext{
${ }^{14}$ Depag RI. al-Qur'an, h.168.
} 
kelompok satu dengan anggota kelompok yang lain membentuk satu ikatan yang kuat seperti bangunan yang kokoh karena tujuan semua kerjasama yang dilakukan wujud dari keimanan mengharap ridha Allah swt.

Dalam hadits yang diriwayatkan oleh Imam Ahmad dari Anas bin Malik, Rasulullah saw bersabda: "Tolonglah saudaramu, baik yang dalam keadaan berbuat zalim atau dizalimi. Ditanyakan; "Ya Rasulullah, aku akan menolong orang yang dizalimi, lalu bagaimana aku akan menolongnya jika ia dalam keadaan berbuat zalim? Beliau saw menjawab; "Menghindarkan dan melarangnya dari kezaliman, itulah bentuk pertolongan baginya"

Selanjutnya Alquran juga menyerukan "Dan janganlah tolong menolong dalam perbuatan dosa dan permusuhan". Perbuatan dosa tentu berdampak untuk pribadi sedangkan akibat perbuatan dosa akan menimbulkan permusuhan. Larangan ini dimaksudkan untuk menjaga manusia tetap berada pada fitrahnya. Perbuatan dosa dan permusuhan sangat merugikan pihak/kelompok lain dalam interaksi sosial. Oleh sebab itu perbuatan ini dilarang karena memang tidak menguntungkan bagi semua pihak. Kerjasama dalam perbuatan dosa dan permusuhan tentu akibat yang ditimbulkannya sangat besar. Larangan ini menjadi titik poin bagi manusia bahwa kerjasama harusnya bukan dilandasi oleh hawa nafsu yang cendrung menghalalkan berbagai cara. Korban dari kerjasama semacam ini adalah kerugian pada pihak lain yang tidak berdosa.

Perbuatan dosa dan permusuhan bukanlah jalan lurus, tapi jalan syetan yang sudah sejak awal menjadi pelopor untuk berbuat kerusakan atau keonaran. Perbuatan dosa dan permusuhan menjadikan individu lain atau kelompok lain menjadi alat untuk pelampiasan hawa nafsu, sehingga proses kehidupan manusia secara keseluruhan menjadi terganggu. Terganggunya kehidupan berarti terhentinya tugas kekhalifahan yang diemban untuk memakmurkan bumi ini. Berkolaborasi individu atau kelompok dalam perbuatan dosa dan permusuhan tidak saja bertentangan dengan fitrah manusia melainkan juga dapat mempercepat datangnya azab Allah. Azab tersebut tidak saja menimpa pada orang yang berbuat dosa tapi juga dapat menimpa orang yang tidak berdosa.

Dosa merupakan beban psikologis bagi orang yang melakukan dan sumber perasaan bersalah. Pengaruh perbuatan dosa secara psikologi adalah perasaan tidak tenang dan tentram dalam menjalani aktifitas sehari-hari. Dari sini muncul ketidakpercayaan diri sehingga untuk munculnya tindakan destruktif semakin besar. Individu yang mendapatkan tekanan batin sedemikian besar dan dibawa dalam kelompoknya menimbulkan apa yang disebut sebagai 
penyakit masyarakat atau patologi sosial. Masyarakat akan terganggu dan tidak nyaman. Ini semua menjadi awal munculnya konflik yang bersifat destruktif.

\section{Sumber Konflik}

Konflik muncul bukan dengan tiba-tiba, tetapi konflik sudah terpuruk sejak awal manusia memulai aktifitasnya baik sebagai individu, anggota masyarakat maupun anggota organisasi tempat dia bekerja. Konflik dengan diri sendiri dapat terjadi pada individu apabila antara hati nurani dengan akalnya tidak sejalan atau bertentangan. Ini sangat berat sekali karena berdampak pada prilaku individu tersebut bahkan dapat mengganggu kesehatan mentalnya.

Mengingat konflik itu bukan muncul secara tiba-tiba, maka konflik memiliki sumber kemunculannya. Dalam pandangan Islam, sumber konflik antara lain:

1. Ego sentris

Simaklah bagaimana kesombongan Iblis yang tidak mau sujud kepada Adam sebagaimana yang diperintah Allah. Keakuan Iblis ini membuat dia membangkang atas perintah Robnya. Dia beranggapan asal kejadiannya dari api lebih baik dari Adam yang diciptakan dari tanah. Sikap sombong atau ego sentris menjadikan individu atau kelompok memandang rendah pihak lain. Sikap memandang rendah orang/kelompok lain melumpuhkan komunikasi, cuek dan acuh tidak acuh. Apa-apa yang baik pada kelompok lain adalah salah yang benar hanya kelompoknya saja. Sikap sombong termasuk penyakit hati yang sulit diobati terlebih jika sudah kronis. Fir'aun berani mengaku sebagai tuhan padahal Iblis yang pembangkang tidak mengakui dirinya tuhan. Itulah buah kesombongan yang tidak dapat menerima kebenaran dari pihak lain. Ego sentris menjadi sarana untuk berkonflik karena kebenaran individu atau kelompok lain tidak dapat diterima oleh individu atau kelompok yang merasa lebih hebat. Ingatlah sejarah kelam aliran Mu'tazilah pada masa dinasti Abbasiyah yang tidak dapat menerima paham lain selain paham mereka.

2. Fitnah

Menuduh pihak lain tanpa dasar adalah fitnah. Begitu besarnya akibat yang ditimbulkan oleh fitnah, Alquran menyebutkannya lebih kejam dari pembunuhan. "Dan fitnah itu lebih besar bahayanya dari pembunuhan"(Q.S.2:191). ${ }^{15}$ Pembunuhan jiwa hanya menghilangkan satu nyawa dan setelah itu selesai. Tetapi fitnah yang sudah

\footnotetext{
${ }^{15}$ Depag RI. al-Qur'an, h.46.
} 
tersebar sulit untuk dibendung dan yang menjadi korban juga lebih besar. Fitnah merupakan sumber konflik yang paling utama dan sebab itulah perbuatan fitnah lebih dahsyat dari pembunuhan. Sebab-sebab fitnah menjadi sumber konflik karena 1). Fitnah dapat membuat kekacauan, 2). Fitnah menjadikan individu atau kelompok saling curiga mencurigai, 3). Pihak yang tidak bersalah atau yang terkena fitnah akan menderita dan menyebabkan dendam yang berkepanjangan.

3. Perubahan lingkungan

Perubahan lingkungan juga dapat menjadi sumber munculnya fitnah disebabkan oleh perbedaan watak dan mental individu atau kelompok. Proses perubahan lingkungan yang cepat terkadang membuat individu atau kelompok belum siap menerimanya sehingga muncul resistensi terhadap perubahan itu. Islam pada awal munculnya di Mekah merupakan satu contoh perubahan lingkungan sebagai sumber konflik. Masyarakat kafir Quraisy di satu sisi dan Nabi Muhammad saw pada sisi lain yang membawa ajaran baru (tauhid) sangat ditolak oleh masyarakat jahiliyah yang sudah mapan dalam semua aspek kehidupannya. Ajaran baru yang dibawa dianggap sebagai ancaman terhadap eksistensi kaum kafir Quraisy.

4. Saluran komunikasi yang tersumbat

Komunikasi yang tidak berjalan dengan baik atau tersumbat bisa menjadi sumber konflik yang berkepanjangan. Penyebab utamanya tidak lain karena pesan-pesan yang disampaikan sulit untuk dipahami oleh anggota organisasi. Dalam teori dakwah disebutkan bahwa da'i harus menyampaikan pesan atau materi dakwah sesuai dengan akal mereka. Pengetahuan segmentasi audien menjadi sangat penting bagi da'i untuk menyesuaikan materi yang akan disampaikan.

5. Kesenjangan sosial

Sumber konflik lainnya yang tidak kalah penting adalah kesenjangan sosial diantara yang kaya dan miskin. Sekalipun komunikasi dapat berjalan dengan baik bila kesenjangan sosial tidak diatasi, maka komunikasi yang lancar tadi tidak membawa hasil yang positif. Untuk mengatasinya tentu kesenjangan sosial yang ada harus lebih dahulu diselesaikan. Sebagai misal sekalipun pemerintah pusat berusaha menjalin komunikasi yang efektif dengan masyarakat Papua bila kesenjangan sosial daerah tersebut tidak diatasi konflik akan tetap hidup. ${ }^{16}$

\footnotetext{
${ }^{16}$ Mulyana. Ilmu Komunikasi, h.115
} 
Islam mengajarkan untuk mengatasi kesenjangan sosial ada sarananya yang disediakan Allah misalnya dengan zakat. Zakat kewajiban setiap individu muslim yang mampu. Didalam harta orang kaya terdapat hak fakir miskin. Zakat menjadi alat untuk meredam konflik sosial yang berujung pada ketegangan sosial itu sendiri. Banyak terjadi revolusi sosial salah satu penyebabnya adalah kesenjangan sosial.

6. Perlakuan tidak adil

Dalam organisasi terkadang terdapat perlakuan tidak adil atasan terhadap seorang bawahan atau individu. Begitu juga dalam masyarakat perlakuan tidak adil misalnya dapat terjadi antara pemimpin dengan rakyat yang dipimpinnya disebabkan perbedaan latar belakang politik.

Perlakuan tidak adil dapat menjadi sumber konflik karena orang atau kelompok yang diperlakukan tidak adil merasa tertekan dan tidak nyaman yang dapat memunculkan sikap destruktif. Kemunculan sikap destruktif bisa saja tidak secara cepat tetapi setelah berjalan bertahun-tahun berada dalam ketidak adilan baru muncul. Kasus tumbangnya Orde Baru merupakan salah satu contoh bahwa perlakuan tidak adil rezim selama 32 tahun terhadap masyarakat/rakyat memunculkan gerakan mahasiswa dan rakyat yang berujung jatuhnya Orde Baru.

Islam memerintahkan kepada pemeluknya untuk berlaku adil terhadap siapapun sekalipun berbeda keyakinan. Perintah ini sebagai antisipasi agar konflik tidak terjadi akibat perlakuan tidak adil.

Perlakuan tidak adil kemungkinan dapat memberikan keuntungan atau manfaat sementara, tapi efek negatif yang akan ditimbulkannya jauh lebih besar dari keuntungan. Oleh karena itulah Islam yang diturunkan oleh Allah tidak memberikan ruang kepada pemeluknya untuk tidak berlaku adil. Firman Allah (Q.S.5:8): "Dan janganlah sekali-kali kebencianmu terhadap sesuatu kaum, mendorong kamu untuk berlaku tidak adil, karena adil itu lebih dekat kepada takwa. Dan bertakwalah kepada Allah, sesungguhnya Allah maha mengetahui apa yang kamu kerjakan”. ${ }^{17}$

Perlakuan adil sejalan dengan tugas manusia sebagai khalifah yang harus melakukan kerjasama dengan semua pihak. Porsi manfaat yang diperoleh masing-masing pihak dari kerjasama tersebut sesuai dengan perannya. Jika setiap individu atau kelompok memiliki peran masing-masing, alasan apalagi untuk tidak berlaku adil?. Perlakuan tidak adil individu atau kelompok terhadap individu atau kelompok lain berarti

\footnotetext{
${ }^{17}$ Depag RI. al-Qur'an, h.159.
} 
menghilangkan peran mereka disebabkan rasa benci. Sifat benci yang melekat pada seseorang mengakibatkan ia bertindak bukan atas akal sehat melainkan berdasarkan hawa nafsu atau perasaan.

\section{Jalan Dakwah}

Dakwah memiliki peran dalam memberikan solusi terhadap konflik. Dari itu seorang muslim yang mukmin dilarang untuk menimbulkan konflik. Sesuai dengan namany "Islam" yang berarti "selamat", karenanya umat Islam adalah umat yang senantiasa berorientasi pada keselamatan diri sendiri, keluarga, masyarakat dan negara. Larangan Islam agar umat Islam tidak menimbulkan konflik karena dia sebagai uswatun hasanah dalam lingkungan sosialnya. Bila dia berdiri sebagai sumber konflik maka tidaka ada lagi uswatun hasanah pada dirinya. Jalan dakwah mencegah konflik sebagai berikut;

1. Berdebat

Jalan dakwah yang ditempuh untuk memberi solusi terhadap konflik yaitu dengan cara berdebat. Perdebatan diperbolehkan oleh Alquran untuk dilakukan terhadap orang-orang kafir agar mereka memperoleh kebenaran. Firman Allah (Q.S.16:125): "Serulah (manusia) kepada jalan Tuhan-mu dengan hikmah dan pelajaran yang baik dan debatlah mereka dengan cara yang baik. Sesungguhnya Tuhanmu Dialah yang lebih baik mengetahui tentang siapa yang tersesat dari jalan-Nya dan Dialah yang lebih mengetahui orang-orang yang mendapat petunjuk". 18

Menurut Tafsir Fi Zhilalil Quran "berdebat dengan cara yang lebih baik. Tanpa bertindak zalim terhadap orang yang menentang ataupun sikap peremehan dan pencelaan terhadapnya. Sehingga seorang dai merasa tenang dan merasakan bahwa tujuannya berdakwah bukanlah untuk mengalahkan orang lain dalam berebat. Akan tetapi untuk menyadarkan, menyampaikan kebenaran kepadanya". ${ }^{19}$

Berdebat seperti di atas, bila pihak yang diajak berdebat tidak dapat memberikan argumentasi sebagai penyokong pendapatnya, maka tidak merasa terpojok atau terkalahkan. Harus diakui bahwa manusia memiliki sifat sombong/keangkuhan yang sulit untuk menerima begitu saja pendapat orang lain. Sikap sombong ini tidak dapat dihadapi dengan cara kasar lagi mencela, tetapi harus dengan kelembutan dan kasih sayang sehingga jiwanya merasa

\footnotetext{
${ }^{18}$ Ibid. h. 421

${ }^{19}$ Sayyid Quthb. Fi Zhilalil Quran, Terjemahan: Tafsir Fi Zhilalil Quran; As'ad Yasin dkk, (Jakarta:
} Gema Insani: 2004),h.24. 
dihormati dan dihargai. Dengan cara seperti inilah keangkuhan dan kesombongannya dapat diredakan, sehingga tujuan dakwah tercapai.

Gaya berdebat yang menyentuh jiwa tidak akan menimbulkan keguncangan batin bagi pihak yang terkalahkan. Mereka tidak merasa kalah tetapi apa yang diperolehnya dari perdebatan semacam itu akan membekas dalam akal dan jiwanya. Hal ini tentu tidak akan memunculkan konflik.

Berdebat tidak dengan cara santun dan lemah lembut, melainkan dengan cara kasar dan disertai celaan terlarang dalam Islam. Hal ini disebabkan cara seperti itu akan menimbulkan luka pada hati/jiwa pihak yang diajak berdebat. Dia merasa dikalahkan atau dipermalukan. Sudah menjadi tabiat manusia bahwa ia akan menghindar manakala sentuhan terhadap jiwanya dirasakan dengan cara yang kasar dan secara spontan respon negatif akan muncul. Allah berfirman (Q.S.2:83): “dan ucapkanlah kata-kata yang baik kepada manusia". 20

2. Musyawarah

Musyawarah atau syura berarti meminta pertimbangan pendapat para ahli dan pakar di bidangnya agar mencapai pertimbangan pendapat dan solusi masalah yang paling mendekati kebenaran. ${ }^{21}$ Definisi ini memberikan penjelasan bahwa musyawarah pada hakikatnya adalah rembukan untuk mencari sebuah solusi terhadap suatu persoalan yang harus segera mendapatkan penanganan. Kaitan musyawarah dengan manajemen konflik adalah dengan bermusyawarah berarti melibatkan orang banyak atau perwakilan dari individu atau kelompok yang berkepentingan. Kepentingan-kepentingan individu atau kelompok dipecahkan atau dicari solusinya secara bersama-sama sehingga hasil musyawarah dapat diterima oleh individu atau kelompok tersebut. Dengan demikian musyawarah dapat mereduksi potensi konflik yang mungkin akan muncul dari sebuah persoalan.

Selain itu, musyawarah dapat menghilangkan kepentingan pribadi atau golongan karena yang ditonjolkan adalah kepentingan bersama. Bila saja dalam musyawarah individu atau kelompok tertentu mendominasi atau memaksakan kehendak, maka musyawarah semacam ini kehilangan makna. Sebagaimana tersirat dalam firman Allah:

"Maka disebabkan rahmat dari Allah-lah kamu berlaku lemah lembut terhadap mereka. Sekiranya kamu bersikap keras lagi berhati kasar, tentulah mereka menjauhkan diri dari sekelilingmu. Karena itu maafkanlah mereka, mohonkanlah ampun bagi mereka dan

\footnotetext{
${ }^{20}$ Depag RI. al-Qur'an, h.23.

${ }^{21}$ Abu Ammar dan Abu Fatih Al Adlani, Mizanul Muslim 2 Barometer Menuju Muslim Kaffah (Solo: Cordova Mediatama,2010), h. 661.
} 
bermusyawarahlah dengan mereka dalam urusan itu. kemudian apabila kamu telah membulatkan tekat, maka bertawakkallah kepada Allah. Sesungguhnya Allah menyukai orang-orang yang bertawakkal kepadanya”.

Satu hal yang penting, apabila musyawarah telah mencapai mufakat/hasil, maka tindakan selanjutnya ialah kebulatan tekat untuk melaksanakan hasil musyawarah, lalu berserah diri atau bertawakkal kepada Allah. Hal ini membawa dampak bahwa musyawarah sebagai salah satu media untuk meminimalisasi konflik dan menjadikan setiap individu atau kelompok tentram dan nyaman karena tidak adanya penyesalan. Demikian ajaran Islam memberikan jalan bagi individu atau kelompok agar menempuh hidup damai. Islam senantiasa memberikan solusi supaya persoalan-persoalan dapat diselesaikan jangan sampai menimbulkan perpecahan.

\section{Penutup}

Konflik merupakan ketetapan dari Allah untuk umat manusia karena sejak diciptakan manusia (Adam) sudah menghadapi konflik dengan Iblis. Konflik pertama membawa korban penumpahan darah terhadap anak Adam, yaitu Habil yang dibunuh oleh Qabil. Sebab itu konflik tetap akan ada sampai hari kiamat. Konflik tidak dapat dihilangkan melainkan dapat dicarikan solusi sehingga pihak yang berkonflik dapat menerima solusi yang diberikan. Kemudian konflik tidak selamanya berkonotasi negatif, tetapi konflik dapat juga bernilai positif yaitu berkompetisi untuk mencapai prestasi sehingga meningkatkan kinerja organisasi dalam rangka mencapai tujuan.

Arti penting manajemen konflik ialah manusia sebagai khalifah sangat berkepentingan untuk mengelola konflik sehingga tujuan untuk memakmurkan bumi dapat tercapai. Sedangkan dalam organisasi mengelola konflik sangat penting artinya agar tujuan organisasi dapat tercapai karena semua sumber daya yang ada diarahkan pada pencapaian tujuan.

Dakwah merupakan cara yang terbaik untuk meminimalisasi konflik karena dakwah merupakan jalan yang diajarkan oleh Allah dan Rasulnya. Dengan debat yang santun dapat meluluhkan pihak yang diajak berdebat karena debat tidak menghakimi atau mengalahkan melainkan menunjukkan jalan kebenaran. Kemudian dengan bermusyawarah berarti melibatkan individu atau kelompok lain untuk terlibat dalam mencari solusi atas sebuah persoalan. Sehingga hasil musyawarah yang diputuskan dapat diterima pihak lain yang berkepentingan. 


\section{Daftar Bacaan}

Abu Ammar dan Abu Fatih Al Adlani, 2010. Mizanul Muslim 2 Barometer Menuju Muslim Kaffah. Solo: Cordova Mediatama.

Deddy Mulyana, 2000. Ilmu Komunikasi Suatu Pengantar. Bandung: Remaja Rosdakrya,2000.

Depag RI, 1993. al-Qur'an dan Terjemahnya. Bandung: CV. Gema Risalah Press.

Departemen Pendidikan dan Kebudayaan, 1995. Kamus Besar Bahasa Indonesia. Jakarta: Balai Pustaka.

Malayu SP Hasibuan, 2000. Manajemen Sumber Daya Manusia. Jakarta: Bumi Aksara.

M. Munir dan Wahyu Ilahi, 2006. Manajemen Dakwah. Jakarta: Kencana.

Wahyudi, 2011. Manajemen Konflik Dalam Organisasi. Bandung : Alfabeta.

William Handricks, 2012. How to Manage Conplict. Terjemahan: Bagaimana Mengelola Konflik.Cet VIII, Arif Santoso. Jakarta: PT. Bumi Aksara.

Sayyid Quthb,2004. Fi Zhilalil Quran,Terjemahan: Tafsir Fi Zhilalil Quran; As'ad Yasin dkk. Jakarta: Gema Insani.

Sondang P.Siagian, 2001. Manajemen Stratejik. Jakarta: PT. Bumi Aksara. 